\title{
Preparation and Ionic Conductivity of Al-Doped $\mathrm{Mg}_{0.5} \mathrm{Ti}_{2}\left(\mathrm{PO}_{4}\right)_{3}$
}

\author{
Hiroo Takahashi* and Hitoshi Takamura \\ Department of Materials Science, Graduate School of Engineering, Tohoku University, Sendai 980-8579, Japan
}

Al-doped $\mathrm{Mg}_{0.5(1+x)} \mathrm{Al}_{x} \mathrm{Ti}_{2-x}\left(\mathrm{PO}_{4}\right)_{3}$ has been prepared by a sol-gel method and the conductivity has been evaluated by an ac impedance method to determine the optimum lattice volume for $\mathrm{Mg}$-ion conduction. Instead of using Ti in the samples, $10-15 \mathrm{~mol} \% \mathrm{Al}$ was used, resulting in lattice contraction in the c-axis direction. The samples, sintered at $500-800^{\circ} \mathrm{C}$ for $12 \mathrm{~h}$ by a reaction sintering method, had a relative density of $70-80 \%$ and their grain size was $2-3 \mu \mathrm{m}$. The ionic conductivity calculated from the grain and grain boundary resistance at $600{ }^{\circ} \mathrm{C}$ was $7.1 \times 10^{-5}$ and $1.3 \times 10^{-5} \mathrm{~S} / \mathrm{cm}$, respectively. The activation energy of the grain conductivity was $128 \mathrm{~kJ} / \mathrm{mol}$ in the temperature range of 300 to $600^{\circ} \mathrm{C}$. By comparing ionic conductivity of various-doped titanium phosphates, optimum lattice volume was estimated to be $1.304 \mathrm{~nm}^{3}$. [doi:10.2320/matertrans.MBW201111]

(Received November 29, 2011; Accepted February 27, 2012; Published April 25, 2012)

Keywords: ionic conductor, phosphate, NASICON-type structure

\section{Introduction}

The NASICON-type crystal structure $\left(\mathrm{A}_{x} \mathrm{M}_{2}\left(\mathrm{XO}_{4}\right)_{3} ; \mathrm{A}=\right.$ alkali and alkaline-earth metal, $\mathrm{M}=$ transition metal, $\mathrm{X}=$ metalloid) as shown in Fig. 1 exhibits A-ion nonstoichiometry and conductivity. The structure has a three-dimensional network frame comprising of $\mathrm{MO}_{6}$ octahedra and $\mathrm{XO}_{4}$ tetrahedra, with A-ions located in the large interstitial sites. NASICON-type materials have been given a great deal of attention in recent years due to their potential as multivalent ionic conductors. Nomura et al. investigated the phase transition and electrical conductivity of zirconium phosphates, $\mathrm{A}^{\mathrm{II}} \mathrm{Zr}_{4}\left(\mathrm{PO}_{4}\right)_{6}(\mathrm{~A}=\mathrm{Mg}, \mathrm{Ca}, \mathrm{Ba}, \mathrm{Mn}, \mathrm{Co}, \mathrm{Ni}, \mathrm{Zn}, \mathrm{Cd}$ and $\mathrm{Pb}) .{ }^{1,2)}$ Imanaka et al. studied $\mathrm{Al}$, rare earth $(\mathrm{Sc}, \mathrm{Eu}, \mathrm{Gd}$, $\mathrm{Er}, \mathrm{Tm}, \mathrm{Yb}$ and $\mathrm{Lu}$ ) and tetravalent ( $\mathrm{Ti}$, Hf and $\mathrm{Ge})$ cation conduction in phosphates and tungstates. ${ }^{3-5)}$ In our previous study, the crystal structure and ionic conductivity of trivalent $\left(\mathrm{Fe}^{3+}, \mathrm{Mn}^{3+}, \mathrm{Co}^{3+}\right)$ - and pentavalent $\left(\mathrm{Nb}^{5+}\right)$-doped $\mathrm{Mg}_{0.5} \mathrm{Ti}_{2}\left(\mathrm{PO}_{4}\right)_{3}$ were studied. $\left.{ }^{6,7}\right)$ Based on the findings in these reports, it is reasonable to assume the existence of an optimum lattice volume with high cation conductivity; large lattice expansion in $\mathrm{Nb}$-doped $\mathrm{Mg}_{0.5} \mathrm{Ti}_{2}\left(\mathrm{PO}_{4}\right)_{3}$ leads to lower ionic conductivity and higher activation energy than in trivalent-doped and undoped $\mathrm{Mg}_{0.5} \mathrm{Ti}_{2}\left(\mathrm{PO}_{4}\right)_{3}$ while smaller cation doping (such as $\mathrm{Co}^{3+}$ ) improves ionic conductivity. To further clarify the relationship between the dopants and ionic conductivity, we investigated the doping of $\mathrm{Mg}_{0.5} \mathrm{Ti}_{2}\left(\mathrm{PO}_{4}\right)_{3}$ with $\mathrm{Al}$, which has a smaller ionic radii $(0.054 \mathrm{~nm})$ than $\mathrm{Co}^{3+}$ $(0.061 \mathrm{~nm}),{ }^{8)}$ and its crystal structure and electrical conductivity were evaluated.

\section{Experimental}

Al- and Fe-doped $\mathrm{Mg}_{0.5} \mathrm{Ti}_{2}\left(\mathrm{PO}_{4}\right)_{3}$ were prepared by the sol-gel method. Two solutions were prepared; in one solution, $\mathrm{Mg}\left(\mathrm{CH}_{3} \mathrm{COO}\right)_{2} \cdot 4 \mathrm{H}_{2} \mathrm{O}$, titanium tetra-butxide tetramer $\mathrm{C}_{4} \mathrm{H}_{9} \mathrm{O}\left[\mathrm{Ti}\left(\mathrm{OC}_{4} \mathrm{H}_{9}\right)_{2} \mathrm{O}_{4} \mathrm{C}_{4} \mathrm{H}_{9} \quad \mathrm{Fe}\left(\mathrm{NO}_{3}\right)_{3} \cdot 9 \mathrm{H}_{2} \mathrm{O}\right.$ and $\mathrm{Al}\left(\mathrm{NO}_{3}\right)_{3} \cdot 9 \mathrm{H}_{2} \mathrm{O}$ were dissolved in ethanol, and in the other, $\mathrm{NH}_{4} \mathrm{H}_{2} \mathrm{PO}_{4}$ was dissolved in distilled water with a concentration of $0.1 \mathrm{~mol} / 1$ separately. These solutions were mixed

*Graduate Student, Tohoku University

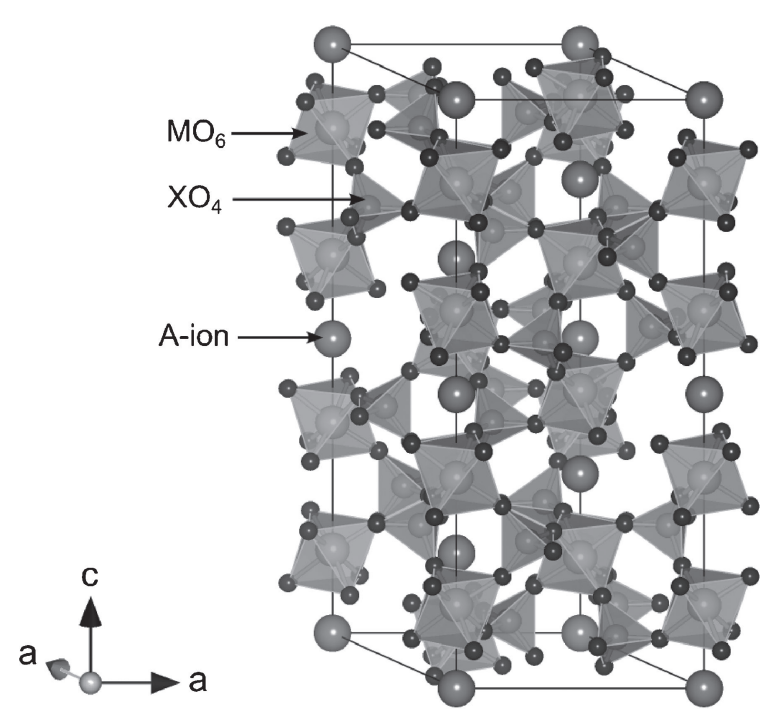

Fig. 1 NASICON-type crystal structure.

into the stoichiometric ratios of the target samples. The obtained gels were dried at $90^{\circ} \mathrm{C}$ for periods of $12 \mathrm{~h}$ or longer and heated at $300^{\circ} \mathrm{C}$ for $12 \mathrm{~h}$. The precursors were pressed into pellets, and then crystallized and sintered at $600-800^{\circ} \mathrm{C}$ for $12 \mathrm{~h}$. Analysis was performed by X-ray diffractmetry (XRD) to identify the phases present. The microstructure was observed by a scanning electron microscope (SEM). To evaluate the electrical conductivity, Pt electrodes were applied on both sides of the sintered samples, and ac impedance measurements were taken in the frequency range of 0.01 to $10^{7} \mathrm{~Hz}$. In order to determine the exact ionic conductivity in the ac impedance measurements, directcurrent measurement was also performed.

\section{Results and Discussion}

Firstly, Al-doped $\mathrm{Mg}_{0.5} \mathrm{Ti}_{2}\left(\mathrm{PO}_{4}\right)_{3}$ was prepared with $\mathrm{Al}$ substituted for Ti sites. In undoped $\mathrm{Mg}_{0.5} \mathrm{Ti}_{2}\left(\mathrm{PO}_{4}\right)_{3}, \mathrm{Mg}$ ions occupy $50 \%$ of all the interstitial sites, whereas in the Aldoped phosphates, the $\mathrm{Mg}$ concentration increases with increasing Al content, and thus holds the charge neutrality. The XRD profiles of $\mathrm{Al}, \mathrm{Fe}$-doped and undoped $\mathrm{Mg}_{0.5^{-}}$ 

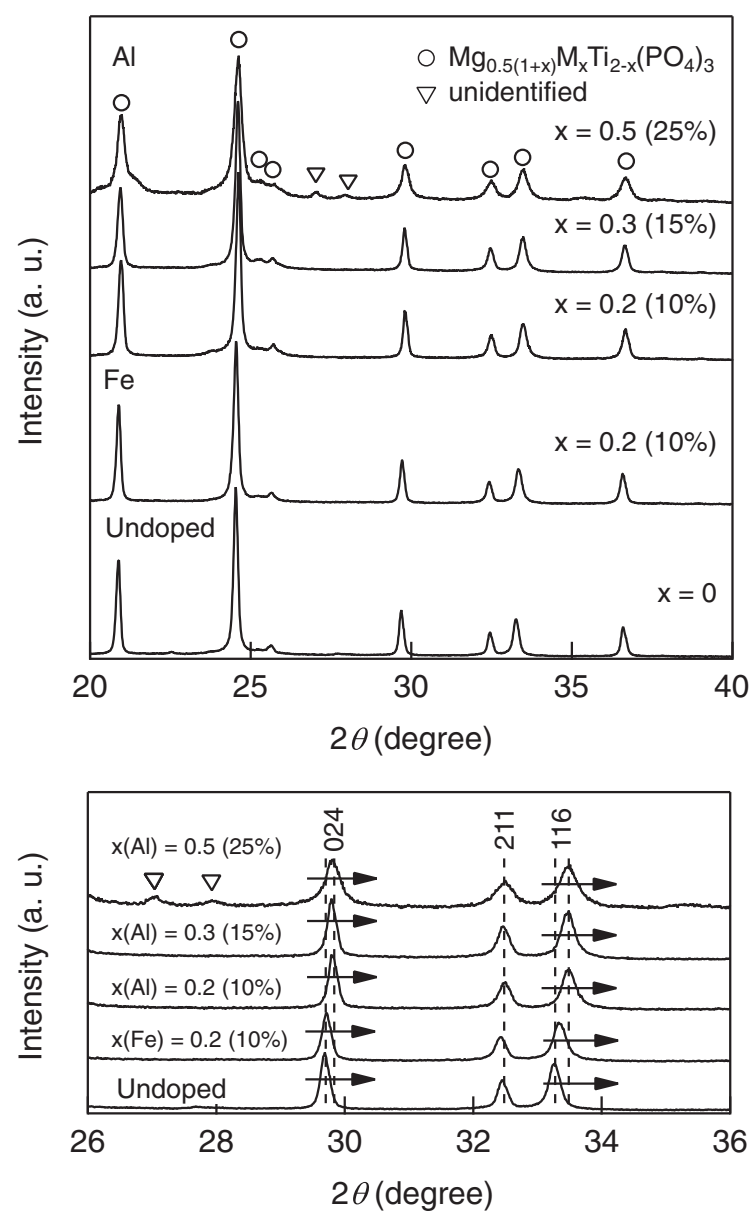

Fig. 2 XRD profiles of Al-, Fe-doped and undoped $\mathrm{Mg}_{0.5} \mathrm{Ti}_{2}\left(\mathrm{PO}_{4}\right)_{3}$ powder.

$\mathrm{Ti}_{2}\left(\mathrm{PO}_{4}\right)_{3}$ are shown in Fig. 2. As the content of the dopants increases, peaks close to the basal planes, such as (024) and (116), shift toward higher angels, indicating lattice contraction in the c-axis direction. Figure 3 shows the lattice constant as a function of dopant content for Al-doped samples and other cation-doped samples. ${ }^{7)}$ The trivalent-doped samples clearly experience lattice contraction in the direction of c-axis, and the Al-doped samples have the smallest lattice constant. In addition, the lattice constant of the $15 \mathrm{~mol} \% \mathrm{Al}-$ doped sample is almost same as that of the sample doped with $10 \mathrm{~mol} \%$, indicating the solubility limit is around $10 \mathrm{~mol} \% \mathrm{Al}$, even though no secondary phase can be seen for the 15 mol\%Al-doped sample in Fig. 2. To see the effect of the dopant on microstructure and ionic conductivity, 10 mol\%Al-, Fe-doped and undoped samples were investigated.

To evaluate the ionic conductivity precisely, a well sintered body is required. For that purpose, the reaction sintering in this study was carried out at lower temperatures than those reported in previous studies. The densification conditions, relative density and grain size of the undoped and doped phosphates are summarized in Table 1, and the SEM images of the samples after reaction sintering at relatively lower temperatures are shown in Fig. 4. Due to its poor sinterbility, $\mathrm{Mg}_{0.5} \mathrm{Ti}_{2}\left(\mathrm{PO}_{4}\right)_{3}$ itself required high sintering temperatures of around $1150-1200^{\circ} \mathrm{C}$; however, such high temperatures resulted in partial decomposition. On the other hand, during the reaction sintering of the precursors at low temperatures,

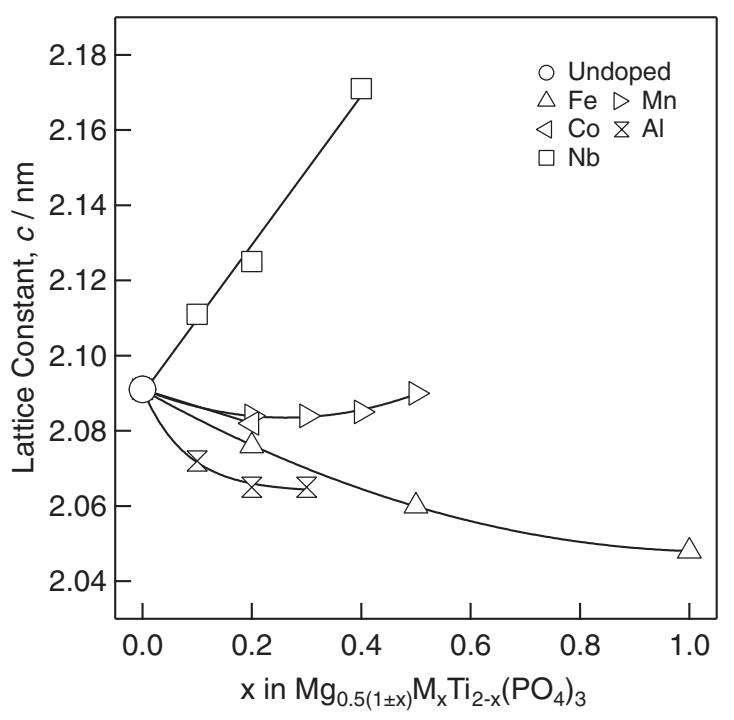

Fig. 3 Lattice constant of doped $\mathrm{Mg}_{0.5} \mathrm{Ti}_{2}\left(\mathrm{PO}_{4}\right)_{3}$ as a function of dopant content.

Table 1 Sintering conditions, relative density and grain size of undoped and doped $\mathrm{Mg}_{0.5} \mathrm{Ti}_{2}\left(\mathrm{PO}_{4}\right)_{3}$.

\begin{tabular}{ccccc}
\hline Compound & Condition & R. D. & Grain size & Phase \\
\hline $\mathrm{Mg}_{0.5} \mathrm{Ti}_{2}\left(\mathrm{PO}_{4}\right)_{3}$ & $1200^{\circ} \mathrm{C}, 10 \mathrm{~h}$ & $76 \%$ & $5-10 \mu \mathrm{m}$ & Dual \\
& $700^{\circ} \mathrm{C}, 12 \mathrm{~h}$ & $80 \%$ & $2-3 \mu \mathrm{m}$ & Single \\
& $($ Reaction sintering) & & & \\
$\mathrm{Mg}_{0.6} \mathrm{Fe}_{0.2} \mathrm{Ti}_{1.8}\left(\mathrm{PO}_{4}\right)_{3}$ & $1150^{\circ} \mathrm{C}, 2 \mathrm{~h}$ & $74 \%$ & $5-10 \mu \mathrm{m}$ & Dual \\
& $750^{\circ} \mathrm{C}, 12 \mathrm{~h}$ & $93 \%$ & $2-3 \mu \mathrm{m}$ & Single \\
& $($ Reaction sintering) & & \\
$\mathrm{Mg}_{0.6} \mathrm{Al}_{0.2} \mathrm{Ti}_{1.8}\left(\mathrm{PO}_{4}\right)_{3}$ & $800^{\circ} \mathrm{C}, 12 \mathrm{~h}$ & $54 \%$ & $2-3 \mu \mathrm{m}$ & Single \\
& $($ Reaction sintering) \\
& $600 \rightarrow 700^{\circ} \mathrm{C}, 12 \mathrm{~h}$ & $72 \%$ & $2-3 \mu \mathrm{m}$ & Single \\
& $($ Reaction sintering) & & \\
\hline
\end{tabular}

the precursors become dehydrated, the ammonium and acetate salts were removed, and the result was a single-phase sample with high relative density. Undoped and $10 \mathrm{~mol} \% \mathrm{Fe}-$ doped $\mathrm{Mg}_{0.5} \mathrm{Ti}_{2}\left(\mathrm{PO}_{4}\right)_{3}$ sintered at 700 and $750^{\circ} \mathrm{C}$ had a higher relative density $(80 \%, 93 \%)$ than samples sintered at $1150-$ $1200^{\circ} \mathrm{C}$, respectively. In the case of $10 \mathrm{~mol} \% \mathrm{Al}$-doped $\mathrm{Mg}_{0.5} \mathrm{Ti}_{2}\left(\mathrm{PO}_{4}\right)_{3}$, two-step sintering, involving pre-sintering at $600^{\circ} \mathrm{C}$ for $12 \mathrm{~h}$ followed by sintering at $700^{\circ} \mathrm{C}$ for $12 \mathrm{~h}$, had better relative density $(72 \%)$ than samples sintered at $800^{\circ} \mathrm{C}$. Grain growth was observed in all the reaction-sintered samples.

By using the ac impedance technique, the electrical conductivity of the samples was measured. Two or three semicircles can be observed in the Nyquist plots of $10 \mathrm{~mol} \% \mathrm{Al}-$, Fe-doped and undoped $\mathrm{Mg}_{0.5} \mathrm{Ti}_{2}\left(\mathrm{PO}_{4}\right)_{3}$ densified by reaction sintering shown in Fig. 5. By fitting an equivalent circuit, the magnitude of capacitances of $10^{-12}$, $10^{-8}$ and $10^{-7} \mathrm{~F}$ were derived from the semicircles observed between high and low frequencies. This suggests that first and other semicircles can be attributed to grain and grain boundary responses, respectively. For the Al-doped samples, a two-probe dc measurement was also performed. The dc conductivity was found to be lower than the grain boundary 

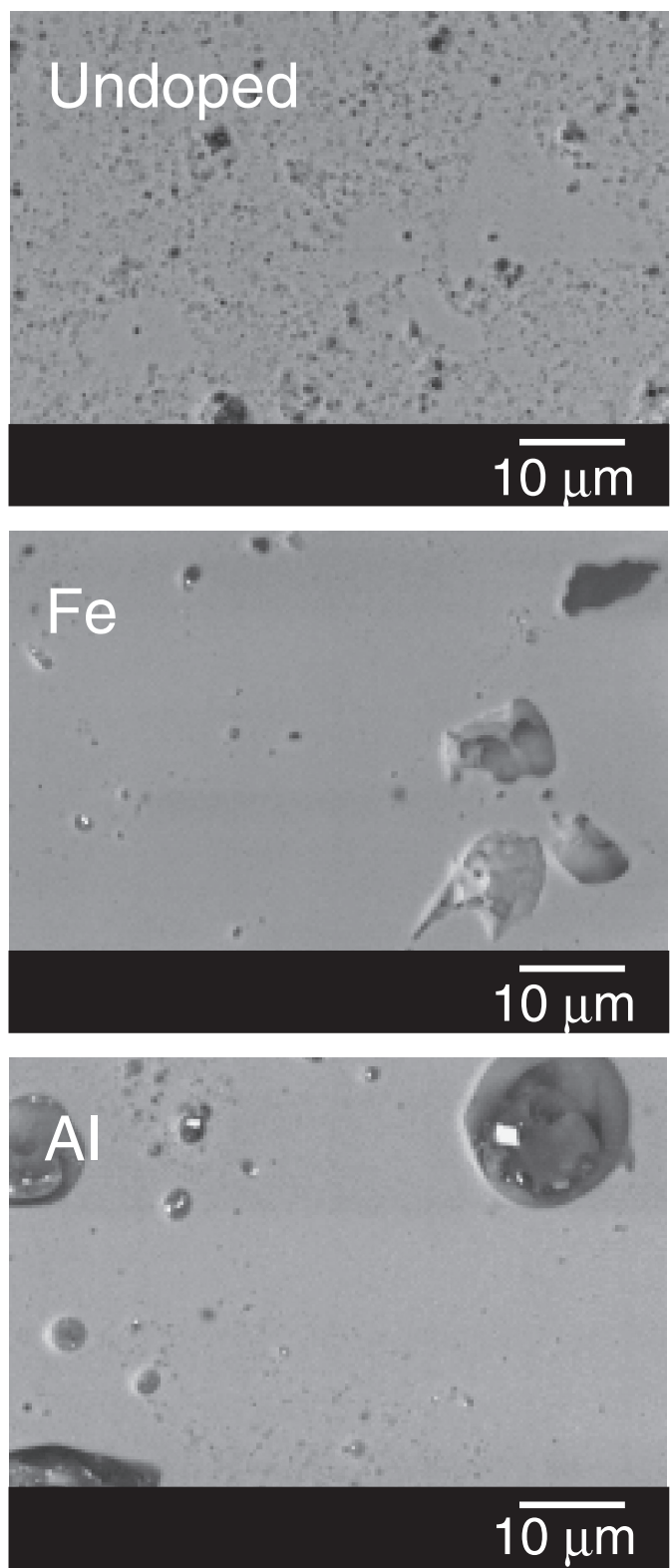

Fig. 4 SEM images of undoped, $10 \mathrm{~mol} \% \mathrm{Fe}$ - and Al-doped $\mathrm{Mg}_{0.5^{-}}$ $\mathrm{Ti}_{2}\left(\mathrm{PO}_{4}\right)_{3}$ after reaction sintering; sintering temperature are 700,750 and 600 to $700^{\circ} \mathrm{C}$, respectively.

conductivity by approximately two orders of magnitude. This suggests that the mobile carrier is ionic, presumably $\mathrm{Mg}^{2+}$. The Arrehnius plots in Fig. 6 show the grain (open markers) and grain boundary (filled markers) ionic conductivity of undoped, $10 \mathrm{~mol} \% \mathrm{Fe}$ - and Al-doped $\mathrm{Mg}_{0.5} \mathrm{Ti}_{2}\left(\mathrm{PO}_{4}\right)_{3}$ densified by reaction sintering. The dashed lines represent the grain conductivity of undoped and $10 \mathrm{~mol} \% \mathrm{Fe}$-doped $\mathrm{Mg}_{0.5} \mathrm{Ti}_{2}\left(\mathrm{PO}_{4}\right)_{3}$ sintered at $1150-1200^{\circ} \mathrm{C}$. The ionic conductivity of the reaction-sintered samples was in good agreement with that for samples sintered at $1150-1200^{\circ} \mathrm{C}$. For $10 \mathrm{~mol} \% \mathrm{Al}$-doped $\mathrm{Mg}_{0.5} \mathrm{Ti}_{2}\left(\mathrm{PO}_{4}\right)_{3}$ the grain and grain boundary conductivity at $600^{\circ} \mathrm{C}$ were $7.1 \times 10^{-5}$ and $1.3 \times 10^{-5} \mathrm{~S} / \mathrm{cm}$, respectively. The ionic conductivity was lower than that for undoped $\mathrm{Mg}_{0.5} \mathrm{Ti}_{2}\left(\mathrm{PO}_{4}\right)_{3}$ by one or two orders of magnitude. The activation energy of $10 \mathrm{~mol} \% \mathrm{Al}-$ doped $\mathrm{Mg}_{0.5} \mathrm{Ti}_{2}\left(\mathrm{PO}_{4}\right)_{3}(128$ and $144 \mathrm{~kJ} / \mathrm{mol})$ was the highest among the samples.
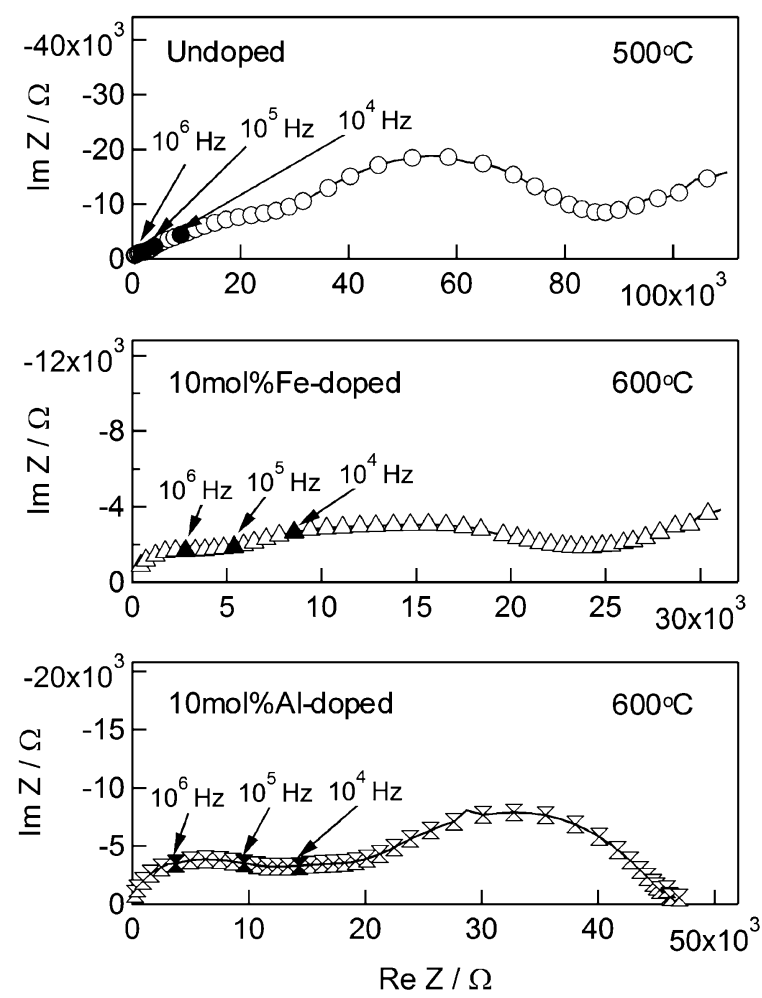

Fig. 5 Nyquist plots of undoped, $10 \mathrm{~mol} \% \mathrm{Fe}$ - and Al-doped $\mathrm{Mg}_{0.5^{-}}$ $\mathrm{Ti}_{2}\left(\mathrm{PO}_{4}\right)_{3}$ measured at 500 or $600^{\circ} \mathrm{C}$.

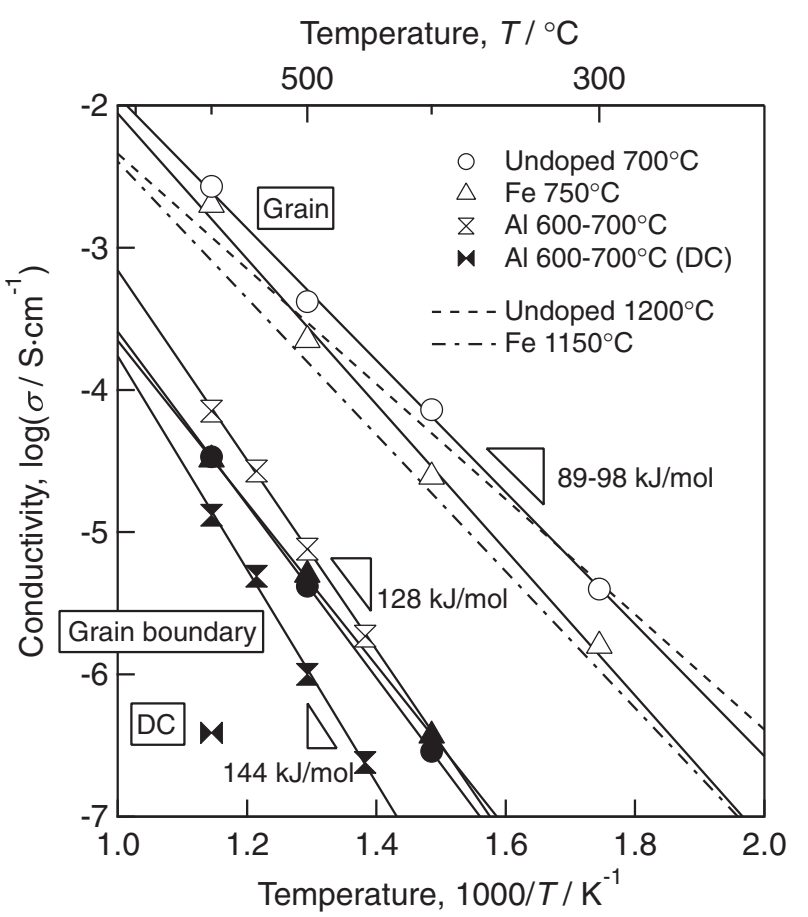

Fig. 6 Arrehnius plots of the grains (open markers) and grain boundaries (filled markers) conductivity of undoped, $10 \mathrm{~mol} \% \mathrm{Fe}$ - and Al-doped $\mathrm{Mg}_{0.5} \mathrm{Ti}_{2}\left(\mathrm{PO}_{4}\right)_{3}$ densified using the reaction sintering method. DC conductivity measured by the two-probe technique was also plotted.

The changes in the ionic conductivity and activation energy can be understood by taking the unit-cell volume into consideration. The grain conductivity and activation energy of $10 \mathrm{~mol} \% \mathrm{M}$-doped $\mathrm{Mg}_{0.5} \mathrm{Ti}_{2}\left(\mathrm{PO}_{4}\right)_{3}$ at $400^{\circ} \mathrm{C}$, where $\mathrm{M}$ denotes $\mathrm{Fe}, \mathrm{Mn}, \mathrm{Co}, \mathrm{Al}$ and $\mathrm{Nb}$, are plotted as a function of 


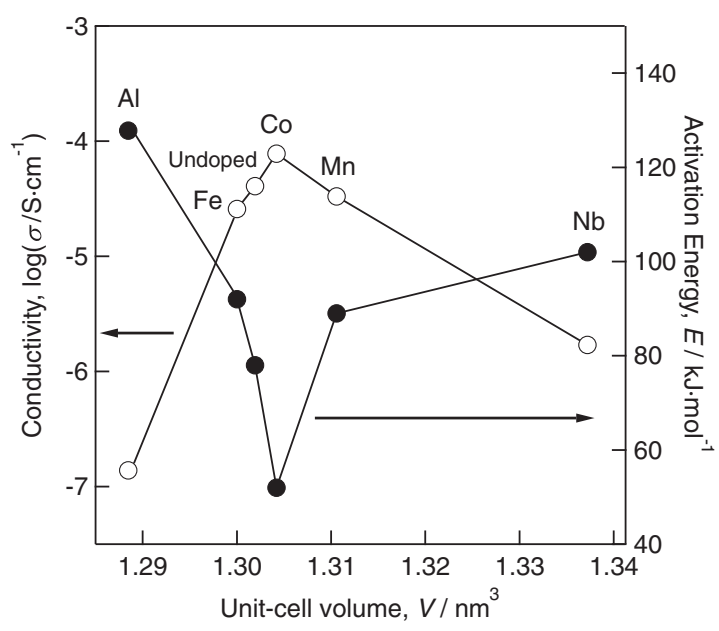

Fig. 7 Grain conductivity and activation energy of $10 \mathrm{~mol} \% \mathrm{M}$-doped $\mathrm{Mg}_{0.5} \mathrm{Ti}_{2}\left(\mathrm{PO}_{4}\right)_{3}$ at $400^{\circ} \mathrm{C}$, where $\mathrm{M}$ donates $\mathrm{Fe}, \mathrm{Mn}, \mathrm{Co}, \mathrm{Al}$ and $\mathrm{Nb}$, as a function of the unit-cell volume.

unit-cell volume in Fig. 7.7) While trivalent doping resulted in a reduction in the c-axis, in the case of Co- and Mn-doped samples, the unit-cell volume increases as a result of expansion in the a-axis. It should be noted that the highest grain conductivity and lowest activation energy were attained for the slightly expanded Co-doped sample. For $10 \mathrm{~mol} \%$ trivalent-doped titanium phosphates, a unit-cell volume of $1.304 \mathrm{~nm}^{3}$ seems to be optimum for $\mathrm{Mg}$-ion conduction. To further clarify the relationship between crystal structure and ionic conductivity, further studies are required for a better understanding of the conduction pathways themselves and their connectivity.

\section{Conclusion}

Al-doped $\mathrm{Mg}_{0.5} \mathrm{Ti}_{2}\left(\mathrm{PO}_{4}\right)_{3}$ was prepared as a single phase NASICON-type structure. The dense and single-phase sample was obtained by reaction sintering. For $10 \mathrm{~mol} \% \mathrm{Al}-$ doped $\mathrm{Mg}_{0.5} \mathrm{Ti}_{2}\left(\mathrm{PO}_{4}\right)_{3}$, the grain and grain boundary conductivity at $600^{\circ} \mathrm{C}$ were $7.1 \times 10^{-5}$ and $1.3 \times 10^{-5} \mathrm{~S} / \mathrm{cm}$, respectively. The activation energy of $10 \mathrm{~mol} \% \mathrm{Al}$-doped $\mathrm{Mg}_{0.5} \mathrm{Ti}_{2}\left(\mathrm{PO}_{4}\right)_{3}(128 \mathrm{~kJ} / \mathrm{mol}$ for the grain conduction) was the highest among various doped phosphates. By comparing the ionic conductivity of the phosphates, the optimum lattice volume was estimated to be $1.304 \mathrm{~nm}^{3}$.

\section{Acknowledgment}

This work was supported in part by Global COE Program "Materials Integration International Center of Education and Research, Tohoku University,” MEXT, Japan.

\section{REFERENCES}

1) K. Nomura, S. Ikeda, K. Ito and H. Einaga: Bull. Chem. Soc. Jpn. 65 (1992) 3221.

2) K. Nomura, S. Ikeda, K. Ito and H. Einaga: Solid State Ion. 61 (1993) 293.

3) N. Imanaka and G.-Y. Adachi: J. Alloy. Compd. 344 (2002) 137.

4) N. Imanaka, M. Itaya, T. Ueda and G. Adachi: Solid State Ion. 154-155 (2002) 319.

5) N. Imanaka and S. Tamura: Bull. Chem. Soc. Jpn. 84 (2011) 353.

6) H. Takahashi, K. Amezawa and H. Takamura: Proc. ECerS XII (2011) No. 2031.

7) H. Takahashi and H. Takamura: Key. Eng. Mater. accepted.

8) R. D. Shannon: Acta Crystallogr. Sec. A 32 (1976) 751. 